\title{
KESIAPAN KABUPATEN SUMBAWA MENJADI KABUPATEN LAYAK ANAK (Ditinjau dari Aspek Penguatan Kelembagaan dan Implementasi Pemenuhan Hak Anak)
}

\author{
Fahrunnisa ${ }^{1},{ }^{2}$ Apriadi \\ Program Studi IImu Komunikasi Fakultas IImu Komunikasi \\ Universitas Teknologi Sumbawa \\ *Corresponding Author email: Fahrunnisa@uts.ac.id, Apriadi@uts.ac.id
}

\begin{tabular}{ll}
\hline \multirow{2}{*}{$\begin{array}{l}\text { Diterima } \\
\text { Bulan September }\end{array}$} & Abstrak \\
\cline { 2 - 2 } 2019 & Kabupaten Sumbawa merupakan salah satu kabupaten yang memiliki angka kekerasan \\
& terhadap anak tertinggi di Provinsi Nusa Tenggara Barat. Berdasarkan data P2TP2A \\
& Kabupaten Sumbawa, jumlah kasus kekerasan terhadap anak pada tahun 2017 berjumlah \\
5iterbitkan & kasus. Hal ini tidak sejalan dengan ditetapkannya kebijakan pemerintah daerah kabupaten \\
Bulan Oktober & Sumbawa untuk mewujudkan Kabupaten Layak Anak (KLA). Penelitian ini bertujuan \\
untuk mengidentifikasi penguatan kelembagaan dan implementasi pemenuhan hak anak & di kabupaten Sumbawa. Metode penelitian yang digunakan adalah penelitian aksi \\
& partisipatif yang melibatkan Organisasi Perangkat Daerah (OPD) yang memiliki tugas \\
Keyword: & dan fungsi dalam pemenuhan hak anak. Hasil dari penelitian aksi ini adalaah \\
Perlindungan & implementasi pemenuhan hak anak belum dapat dilakukan sepenuhnya oleh pemerintah \\
Anak; Hak Anak; $;$ & koorah, hal ini disebabkan oleh kapasitas kelembagaan belum memadai karena lemahnya \\
Kabupaten $/$ Kota & \\
Layak Anak &
\end{tabular}

\section{PENDAHULUAN}

Anak merupakan generasi penerus suatu bangsa, tumbuh kembang anak menjadi hal yang penting untuk diperhatikan terutama dalam pemenuhan hak dasar anak. Dalam Convention on The Rights of The Children, negara memberikan pengakuan serta menjamin penghormatan, perlindungan dan pemenuhan hak-hak anak. Konvensi Hak Anak (KHA) bersifat mengikat bagi negara-negara yang telah menandatangani dan meratifikasinya, Indonesia salah satu negara yang telah meratifikasi konvensi tersebut melalui Keputusan Presiden Nomor 36 tahun 1990.

Dalam rangka mempercepat implementasi KHA, pemerintah melalui Kementrian Pemberdayaan Perempuan dan Perlindungan Anak (KP3A) Republik Indonesia menerbitkan Peraturan Menteri Nomor 11 Tahun 2011 tentang Kebijakan Pengembangan Kabupaten/Kota Layak Anak (KLA). Konsep KLA ini menekankan pembangungan berbasis hak anak melalui pengintegrasian komitmen dan sumber daya pemerintah, masyarakat dan dunia usaha, yang terencana secara menyeluruh dan berkelanjutan dalam kebijakan, program dan kegiatan untuk menjamin terpenuhinya hak dan perlindungan anak.

Melalui kebijakan Kabupaten/Kota Layak Anak, pemerintah berupaya mewujudkan Indonesia yang layak bagi anak. KLA bertujuan untuk membangun inisiatif pemerintah Kabupaten/Kota yang mengarah pada upaya transformasi konsep hak anak ke dalam kebijakan, program, dan kegiatan untuk menjamin terpenuhinya hak anak di kabupaten/kota. Hak anak meliputi: a) hak sipil dan kebebasan; b) lingkungan keluarga dan pengasuhan alternatif; c) kesehatan dasar dan kesejahteraan; d) pendidikan, pemanfaatan waktu luang, dan kegiatan budaya; e) perlindungan khusus. Kebijakan ini diimplimentasikan dalam prinsip-prinsip tata pemerintahan yang baik, yaitu transparansi, akuntabilitas, partisipasi, keterbukaan informasi, dan supremasi hukum; non-diskriminasi; kepentingan terbaik bagi anak; hak untuk hidup, kelangsungan hidup, dan perkembangan anak; dan penghargaan terhadap pandangan anak. (Permen KP3A no.11, 2011).

Inisiasi Kabupaten/Kota Layak Anak menjadi keharusan bagi setiap daerah, mengingat sekitar 83 juta $(32,24 \%)$ dari 258 juta penduduk Indonesia adalah anak, pada tahun 2017 kabupaten dan kota yang telah menginisiasi pengembangan KLA tercatat 349 dari 516 kabupaten/kota. (JawaPos 2017). Kabupaten Sumbawa merupakan salah satu daerah yang berkomitmen mewujudkan Kabupaten Sumbawa Layak Anak tahun 2021. Hal ini sejalan dengan Rencana Pembangunan Jangkah Menengah Daerah (RPJM) tahun 2016-2021, pada misi pertama yaitu" meningkatkan kualitas sumber daya manusia melalui peningkatan kualitas Pendidikan dan peningkatan derajat kesehatan masyarakat". 
Percepatan pemenuhan hak anak di Kabupaten Sumbawa secara spesifik tertuang dalam strategi kelima RPJM yaitu mewujudkan Kabupaten Sumbawa Layak Anak. Sasaran dari aktivitas ini ialah tercapainya klaster hak anak yang ditandai dengan pemenuhan hak anak. Namun, sejak pemerintah daerah mulai mengimplementasikan kebijakan KLA tahun 2017 angka kekerasan terhadap anak meningkat pada tahun 2018. Berlandas pada kondisi tersebut, maka penelitian ini diarahkan untuk mengidentifikasi penguatan kelembagaan dan implementasi pemenuhan hak anak di Kabupaten Sumbawa.

\section{METODE PENELITIAN}

Penelitian ini merupakan penelitian aksi partisipatif, yaitu penelitian yang melibatkan secara aktif semua pihak-pihak yang relevan (stakeholders) dalam mengkaji tindakan yang sedang berlangsung (dimana pengalaman mereka sendiri sebagai persoalan) dalam rangka melakukan perubahan dan perbaikan ke arah yang lebih baik (Agus,2014). Adapun fokus penelitian ini ialah pada analisis kapasitas kelembagaan dan implementasi pemenuhan hak dasar anak dalam mewujudkan Kabupaten Sumbawa Layak Anak.

Lokasi penelitian di lingkungan Pemerintahan Kabupaten Sumbawa yang berdurasi selama 9 Bulan sejak April 2018 hingga Desember 2018 dengan melibatkan Organisasi Perangkat Daerah (OPD) yang berkepentingan dengan pemenuhan hak anak, yaitu Badan Perencanaan Pembangunan Daerah, Dinas Pengendalian Penduduk Keluarga Berencana Pemberdayaan Perempuan dan Perlindungan Anak, Dinas Sosial, Dinas Kesehatan, Dinas Pendidikan, Dinas Kominfotik dan Unit Pelayanan Perempuan dan Anak Polres Kabupaten Sumbawa. Penelitian ini juga melibatkan kelompok-kelompok yang memiliki fokus kajian maupun program dalam upaya pemenuhan hak anak di Kabupaten Sumbawa.

Data yang digunakan dalam penelitian aksi partisiparif ini adalah data primer dan data skunder, data skunder diperoleh dari desk study yaitu dengan mengumpulkan hasil-hasil kajian terdahulu, laporan-laporan kegiatan di daerah yang berhubungan dengan anak dan laporan program kerja OPD yang terkait. Sementara itu, data primer diperoleh melalui observasi partisipasi, wawancara mendalam dan Focus Grup Discussion.

\section{PEMBAHASAN}

\section{Urgensi Kabupaten Sumbawa Layak Anak}

Kabupaten Sumbawa memiliki jumlah penduduk 449.680 jiwa pada tahun 2017, dari jumlah penduduk tersebut $36 \%$ merupakan anakanak. Adapun data anak berdasarkan kelompok usia pada tahun 2017 yaitu kelompok usia 0-14 tahun berjumlah 129.793 jiwa, dan kelompok usia 15-19 tahun berjumlah 35.739 jiwa (BPS 2017). Dalam kurun waktu 3 tahun yaitu 2016-2018, angka kekerasan anak di Kabupaten Sumbawa terus meningkat. Adapun data kekerasan terhadap anak di Kabupaten Sumbawa sebagai berikut: (Grafik 1)

Gafik. 1. Data Kasus Kekerasan Terhadap Anak di Kabupaten Sumbawa (2017-2018)

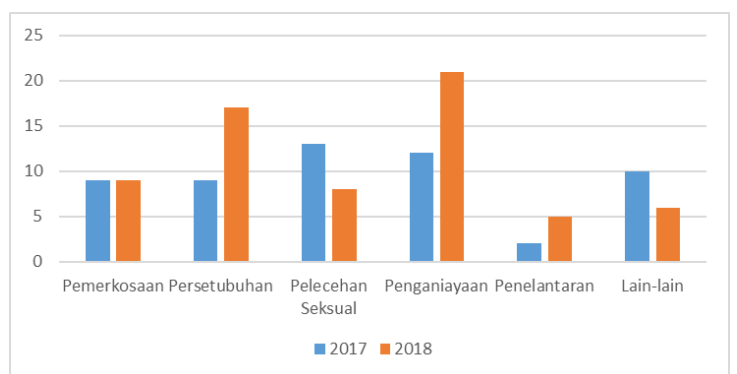

Sumber: DP2KBP\#A Kabupaten Sumbawa

Berdasarkan grafik di atas, data kasus kekerasan anak di Kabupaten Sumbawa pada tahun 2017 berjumlahn 55 kasus, yaitu Pemerkosaan 9 kasus, persetubuhan 9 kasus, pelecehan seksual 13 kasus, penganiayaan 12 kasus, Penelantaran 2 kasus dan lain-lain 10 kasus. Sementara itu, kasus kekerasan di tahun 2018 mencapai 66 kasus, yaitu Pemerkosaan 9 kasus, persetubuhan 17 kasus, pelecehan seksual 8 kasus, penganiayaan 21 kasus, Penelantaran 5 kasus dan lain-lain 6 kasus. Dari data kasus kekerasan anak tahun 2017-2018, anak perempuan dominan menjadi korban kekerasan pada kasus pelecehan seksual, persetubuhan dan pemerkosaan. Sementara anak laki-laki dominan menjadi korban pada kasus penganiayaan dan penelantaran. Dari data kasus tersebut juga menunjukkan angka kasus penganiayaan meningkat $57 \%$ dan kasus persetubuhan meningkat $53 \%$.

Inisiatif pembentukan Kabupaten Sumbawa Layak Anak merupakan langkah strategis yang di tempuh oleh pemerintah daerah untuk memberikan ruang partisipasi, perlindungan dan pemenuhan hak anak. dalam melaksanakan kebijakan KLA tersebut, ada beberapa prinsip dasar yang wajib dipenuhi, yaitu tata kelola pemerintahan yang baik dan akuntabilitas, non-diskriminasi, kepentingan terbaik untuk anak, penghargaan terhadap pandangan anak. Kabupaten Sumbawa dapat dikategorikan Kabupaten Layak Anak apabila telah memenuhi hak anak yang diukur dengan indikator KLA, yaitu penguatan kelembagaan dan pemenuhan hak anak melalui 5 klaster (Permen P3A No. 12, 2011).

\section{Identifikasi Penguatan Kelembagaan}

Penguatan kelembagaan dalam konsep pengembangan KLA mencakup: (a) tersedianya peraturan/kebijakan daerah tentang KLA dan alokasi anggaran untuk implementasi kebijakan; (b) terbentuknya Gugus Tugas Kabupaten Layak Anak 
yang melibatkan forum anak, (c) terbentuknya Kecamatan Layak Anak (KELANA) dan Desa Layak Anak (DEKELA); (d) tersedianya profil anak; (e) tersusunya Rencana Aksi Daerah; dan (f) keterlibatan lembaga kemasyarakatan, dunia usaha dan media massa. (Permen P3A No.12, 2011).

Penguatan kelembagaan KLA di Kabupaten Sumbawa mulai dilaksanakan sejak tahun 2017 yang di inisiasi oleh Dinas Pengendalian Penduduk Keluarga Berencana, Pemberdayaan Perempuan dan Perlindungan Anak Kabupaten Sumbawa. Beberapa aspek penguatan kelembagan yang sudah dicapai oleh kabupaten Sumbawa adalah: (a) telah terbentuknya Gugus Tugas Kabupaten Sumbawa Layak Anak dan tim penyusun Rencana Aksi Daerah, (b) terbentuknya Forum Anak Samawa (FAS), dan (c) tersusunnya Peraturan Daerah tentang Perlindungan Anak yang merupakan bagian dari KLA.

Gugus Tugas di Kabupaten Sumbawa terbentuk berdasarkan SK Bupati Nomor 1372 tahun 2017 tentang Gusug Tugas Kabupaten Layak Anak. Gugus Tugas KLA diketuai oleh Kepala Badan Perencanaan Pembangunan, Penelitian dan Pengembangan Daerah (Bappelitbangda) Kabupaten Sumbawa. Gugus Tugas KLA terbagi ke dalam 5 kelompok berdasarkan klaster hak anak dan 1 kelompok penguatan kelembagaan.

Keberadaan Gugus Tugas KLA di Kabupaten Sumbawa diharapkan menjadi lembaga yang mengkoordinasikan upaya kebijakan, program dan kegiatan untuk mewujudkan KLA. Namun pada kenyataannya, satu tahun terbentuknya Gugus Tugas KLA belum menjalankan fungsi dan tanggung jawab sesuai dengan SK Bupati tersebut. Padahal di tahun 2017 target implementasi KLA sebesar $60 \%$ dengan rencana anggaran lebih besar dari tahun 2016 (LKJIP DP2KBP3A, 2017). Di tahun 2017, Gugus Tugas KLA hanya melaksanakan rapat koordinasi sebanyak satu kali, namun tidak diketahui hasil dan rencana tindak lanjut dari pertemuan tersebut.

Perwakilan Organisasi Perangkat Daerah (OPD) yang tergabung dalam Gugus Tugas KLA belum sepenuhnya memahami fungsi dan tanggung jawabnya, sehingga belum terjalin koordinasi dan komunikasi yang efektif baik di internal maupun eksternal kelompok klaster Gugus Tugas. Hal ini dibuktikan dengan belum adanya capaian berbentuk perencanaan program maupun kegiatan dari Gugus Tugas KLA. Disisi lain, keberadaan perwakilan OPD dalam Gugus Tugas KLA belum dapat mengidentifikasi program-program yang berkaitan dengan anak untuk dikolaborasikan sehingga dapat mendukung satu sama lain. Padahal program kerja lintas OPD diharapkan menjadi bagian dalam implementasi KLA belum sepenuhnya tersingkronisasi. Sebagai bagian dari penguatan kelembagaan KLA di Kabupaten Sumbawa, Dinas P2KBP3A juga menginisiasi terbitnya Peraturan
Daerah Nomor 7 Tahun 2017 tentang Penyelenggaraan Perlindungan Anak yang dianggap sebagai bagian dari KLA.

\section{Implementasi Pemenuhan Hak Anak}

Pemenuhan hak anak merupaksan salah satu indikator yang harus dipenuhi oleh kabupaten/kota agar dapat menjadi Kabupaten/Kota Layak Anak, dalam pemenuhan hak anak terdapat lima klaster hak anak yang harus dipenuhi oleh Kabupaten Sumbawa untuk mewujudkan Kabupaten Sumbawa Layak Anak. Lima klaster hak anak tersebut meliputi: (1) Hak sipil dan kebebasan, (2) Lingkungan keluarga dan pengasuhan alternatif, (3) Kesehatan dasar dan kesejahteraan, (4) Pendidikan, pemanfaatan waktu luang, dan kegiatan budaya, (5) Perlindungan Khusus. (Permen P3A no. 12, 2011)

Adapun implementasi yang telah dilakukan oleh Kabupaten Sumbawa dalam pemenuhan hak anak yang terbagi ke dalam 5 klaster tesebut, serta indikator-indikator yang belum dapat dicapai dan dipenuhi oleh Kabupaten Sumbawa adalah sebagai berikut:

\section{a. Hak Sipil dan Kebebasan}

Klaster ini mencakup pemenuhan hak anak, yaitu hak atas identitas; hak perlindungan identitas; hak berekspresi dan mengeluarkan pendapat; hak berpikir, berhati nurani, dan beragama; hak berorganisasi dan berkumpul secara damai; hak atas perlindungan kehidupan pribadi; hak akses informasi yang layak; serta hak bebas dari penyiksaan dan penghukuman lain yang kejam, tidak manusiawi atau merendahkan martabat manusia.

Implementasi pemenuhan hak sipil dan kebebasan pada anak di kabupaten Sumbawa yang telah dilakukan oleh pemerintah daeah adalah telah tersedianya data jumlah anak berusia $0-<18$ tahun di Dinas Kependudukan dan Catatan Sipil (Dukcapil), pembuatan Akta Kelahiran telah digratiskan untuk usia $0-<18$ tahun, dan telah terbentuk Forum Anak Sumbawa (FAS) pada tahun 2017 melalui SK Bupati Nomor 952 dengan tujuan untuk mengupayakan terwujudnya pemenuhan hak dasar anak di Kabupaten Sumbawa secara optimal dan melakukan advokasi terhadap kondisi yang diduga melanggar pemenuhan hak anak dan membentuk jaringan kerja dengan masyarakat dan lembaga yang fokus dalam pemenuhan hak anak. Pada tahun 2017 juga telah terbentuk 1 forum anak kecamatan dari 24 kecamatan di Kabupaten Sumbawa yaitu di Kecamatan Tarano.

Sementara itu, beberapa indikator yang belum dapat dipenuhi atau dicapai oleh pemerintah daerah adalah tidak terpenuhinya target nasional $(78,25 \%)$ terkait persentase anak yang sudah mendapatkan Akta Kelahiran tahun 
2017 yaitu 78, 25\%, belum tersedianya kebijakan tentang percepatan pelaksanaan registrasi kelahiran dan pemberian kutipan Akta Kelahiran, serta belum menjadi fokus pemerintah daerah tentang Kartu Identitas Anak (KIA) sehingga data anak yang mendapatkan KIA belum ada, disisi lain data KIA merupakan basis data profil anak di Kabupaten Sumbawa. Pemerintah daerah belum memiliki kebijakan atau regulasi terkait dengan layanan Informasi Layak Anak (ILA), sehingga dengan terjadinya kekosongan kebijakan mengakibatkan anakanak tidak dapat mengakses segala informasi sesuai usia dan orang tua tidak memperoleh pemahaman mengenai konten yang layak anak karena keterbatasan informasi. Disamping itu, Forum Anak Samawa belum dilibatkan dalam proses perencanaan pembangunan daerah, sehingga keberadaan forum anak di tingkat kabupaten nyatanya belum mengakomodir dan menghimpun aspirasi maupun permasalahan yang terjadi pada anak di kabupaten Sumbawa.

\section{b. Lingkungan Keluarga dan Pengasuhan Alternatif \\ Klaster ini meliputi beberapa aspek, yaitu:} bimbingan dan tanggungjawab orang tua; anak yang terpisah dari orang tua; reunifikasi (pertemuan kembali anak dengan orang tua setelah terpisahkan); pemindahan anak secara illegal; dukungan kesejahteraan bagi anak; anak yang terpaksa dipisahkan dari lingkungan keluarga; pengangkatan/adopsi anak; tinjauan penempatan secara berkala; serta kekerasan dan penelantaran.

Implementasi pemenuhan hak anak pada klaster lingkungan keluarga dan pengasuhan alternatif yang telah dicapai dan dipenuhi oleh kabupaten Sumbawa yaitu, telah tersedianya data tentang angka perkawinan anak dan upaya pencegahan yang dilakukan pemerintah daerah, tersedianya kebijakan dan regulasi terkait pengasuhan alternatif serta telah dibentuk 12 LKSA (Lembaga Kesejahteraan Sosial Anak) dan Lembaga Konsultasi Kesejahteraan Keluarga (LK3). Namun, 12 LKSA yang sudah ada di kabupaten Sumbawa belum ada LKSA yang terakreditasi, padahal akreditasi ini menjadi penting dimiliki LKSA untuk legalitas dan akses pendanaan serta fasilitas lainnya.

Beberapa indikator lain yang belum mampu dipenuhi pemerintah daerah adalah belum tersedianya lembaga pengasuhan alternatif untuk anak disabilitas serta belum tersedianya data tentang anak disabilitas dan anak disabilitas yang diadopsi. Kabupaten Sumbawa belum memiliki kebijakan tentang Ruang Bermain Ramah Anak (RBRA), dan belum tersedianya data tentang sekolah yang memiliki RASS (Rute Aman dan Selamat ke/dari Sekolah) serta fasilitas pejalan kaki dan penyebrangan di sekitar sekolah yang dapat diakses oleh disabilitas di Kabupaten Sumbawa.

c. Kesehatan Dasar dan Kesejahteraan

Klaster ini meliputi beberapa aspek, yaitu: anak penyandang disabilitas; kesehatan dan layanan kesehatan; jaminan sosial layanan dan fasilitasi kesehatan; serta standar hidup. Implementasi hak anak pada klaster kesehatan dasar dan kesejahteraan yang telah dicapai oleh kabupaten Sumbawa adalah angka rata-rata persalinan di fasilitas kesehatan tahun 2017 di atas angka nasional $(73,6 \%)$ yaitu mencapai $87.6 \%$, dibarengi dengan angka cakupan kepemilikin buku KIA mencapai $94.71 \%$. Selanjutnya, angka dan persentase masalah gizi lebih yaitu 1.61\% (765 Balita) masih di bawah angka nasional (11.8\%), dan persentase ASI ekslusif bagi bayi usia 0-6 bulan tahun 2017 mencapai $88.7 \%$ diatas angka nasional $(52.3 \%)$, dan persentase bayi yang menerima MP-ASI (Makanan Pendamping ASI) dan anak pada usia 2 tahun mencapai $91.61 \%$.

Di kabupaten Sumbawa juga telah memiliki SDM konselor ASI baik di kabupaten maupun di kecamatan yang berjumlah 49 orang serta kader PMB (Pemberian Makan pada Bayi) 365 orang pada tahun 2018. Tersedianya Puskesmas yang ramah anak yaitu 5 Puskesmas (2017) dan 11 Puskesmas (2018), persentase rumah tangga yang mendapatkan air minum layak mencapai $69 \%$ dan sarana sanitasi yang layak mencapai 80\%. Kabupaten Sumbawa juga telah mengesahkan Peraturan Daerah tentang KTR (Kawasan Tanpa Rokok) melalui Perda No.7 tahun 2016.

Beberapa indikator yang belum dapat dicapai dan dipenuhi oleh pemerintah daerah kabupaten Sumbawa adalah angka kematian bayi yang masih relatif tinggi, pada tahun 2017 berjumlah 54 bayi dan persentase balita kekurangan gizi mencapai 5.49\%. Data persentase stunting yang kontras dengan data nasional, berdasarkan data nasional tahun 2017 kasus stunting di Kabupaten Sumbawa lebih tinggi $20 \%$ dari angka nasional, sementara angka stunting dari dinas kesehatan kabupaten Sumbawa yaitu $11.53 \%$, perbedaan data tersebut dikarenakan alat pengukuran yang digunakan dinas kesehatan Kabupaten Sumbawa belum sesuai standar yang digunakan di tingkat nasional.

Kabupaten Sumbawa juga belum memiliki data tentang angka dan persentase ruang Ibu menyusui di perkantoran, fasilitas umum dan ruang publik, serta belum tersedianya rumah sakit sayang ibu dan bayi. Disamping itu, terkait regulasi perda tentang Kawasan Tanpa Rokok yang telah disahkan tahun 2016, 
kabupaten Sumbawa belum memiliki data dan persentase kawasan tanpa rokok di fasilitas kesehatan, fasilitas pendidikan, fasilitas tempat ibadah dan fasilitas umum belum bebas asap rokok, belum ada fasilitas ruang merokok serta pemerintah daerah belum sepenuhnya menolak iklan rokok sehingga masih ada beberapa iklan rokok di ruang publik dan sponsor rokok di acara sekolah.

d. Pendidikan, Pemanfaatan Waktu Luang dan Kegiatan Budaya

Klaster ini meliputi beberapa aspek, yaitu: pendidikan; tujuan pendidikan; serta kegiatan liburan, dan kegiatan seni dan budaya. Implementasi hak anak pada kalster ini yang telah dipenuhi oleh pemerintah daerah kabupaten Sumbawa adalah telah tersedianya kebijakan dan regulasi mengenai PAU-HI melalui Peraturan Bupati No. 14 tahun 2013, telah dibentuk 600 PAUD-HI yang tersebar di 165 desa di Kabupaten Sumbawa. Tercapainya program wajib belajar 12 tahun, dimana program wajib belajar 9 tahun (SD dan SMP) dilaksanakan oleh Dinas Pendidikan Kabupaten Sumbawa, sementara program wajib belajar ditingkat SMA dijalankan oleh Dinas Pendidikan Provinsi NTB.

Indikator yang belum mampu dipenuhi oleh pemerintah daerah adalah belum adanya kebijakan untuk mendorong terwujudnya Sekolah Ramah Anak (SRA) di kabupaten Sumbawa dan pemerintah daerah belum memiliki data tentang angka dan persentase sekolah tingkat SD dan SMP yang telah menjadi Sekolah Ramah Anak. Pemerintah kabutaen Sumbawa belum memiliki regulasi tentang budaya, kreatifitas dan rekreasi untuk anak, dan fasilitas Pusat Kreatifitas Anak (PKA) hanya tersedia di gedung kesenian di Desa Kerato yang tidak dapat diakses oleh disabilitas.

e. Perlindungan Khusus

Klaster ini meliputi beberapa aspek, yaitu: anak dalam situasi darurat; anak yang berhadapan dengan hukum $(\mathrm{ABH})$; anak dalam situasi eksploitasi; serta anak yang masuk dalam kelompok minoritas dan terisolasi.

Dalam klaster ini indikator yang telah dipenuhi oleh pemerintah daerah adalah telah tersedianya kebijakan tentang korban anak, kekerasan dan penelantaran melalui Perda No. 32013 tentang P2TP2A dan Perda No. 7 Tahun 2017 tentang Penyelenggaraan Perlindungan Anak, telah tersedia lembaga layanan bagi anak korban kekerasan dan penelantaran yaitu P2TP2A, LK3 dan LPA. Adapun data tentang angka dan persentase anak korban kekerasan dan penelantaran yang terlayani pada tahun
2018 berjumlah 16 anak dari 39 anak. Sementara $\mathrm{ABH}$ yang menjalani diversi pada tahun 2018 sejumlah 8 anak.

Sementara itu, indikator-indikator yang belum terpenuhi atau terlaksana di klaster perlindungan khusus adalah belum tersedianya mekanisme rujukan, monitoring dan pelaporan anak korban kekerasan dan penelantaran, belum tersedianya SDM psikolog dan psikiater, dan SDM yang terlatih KHA. Kebijakan tentang pekerja anak serta alokasi anggaran juga belum tersedia, kondisi ini juga diperburuk dengan tidak tersedianya data lembaga bagi penarikan pekerja anak, SOP pencegahan, mekanisme pengawasan terhadap pekerja anak, pencatatan dan pelaporan pekerja anak, serta belum ada data anak yang terlibat BPTA (Bentuk-bentuk Pekerjaan Terburuk Untuk Anak). Dalam situasi darurat bencana, pemerintah daerah belum memiliki early warning system bencana yang dipahami anak, serta belum tersedia jalur evakuasi ramah anak. serta belum ada mekanisme pencatatan dan pelaporan anak disabilitas. Disamping itu, kabupaten Sumbawa belum memiliki peraturan tentang anak korban jaringan terorisme maupun stigmatisasi, dan upaya pencegahannya.

Keterlibatan masyarakat juga dapat berbentuk pemberdayaan keluarga/masyarakat sekitar, program bersama, penyediaan fasilitas, penyediaan layanan tumbuh kembang dan perlindungan anak, dan/atau penyediaan dana. Peran dunia usaha dilakukan melalui: kebijakan perusahaan yang berperspektif Anak; produk yang ditujukan untuk Anak harus aman bagi Anak; dan berkontribusi dalam pemenuhan Hak Anak melalui tanggung jawab sosial perusahaan. Sedangkan peran media massa dilakukan melalui penyebarluasan informasi dan materi edukasi yang bermanfaat dari aspek sosial, budaya, pendidikan, agama, dan kesehatan anak dengan memperhatikan kepentingan terbaik bagi anak.

Lembaga Masyarakat, Dunia Usaha, dan Media Massa dapat membentuk asosiasi masingmasing yang peduli terhadap pemenuhan hak dan perlindungan anak di tingkat Kabupaten/Kota. Sebagai contoh saat ini telah terbentuk Asosiasi Perusahaan Sahabat Anak Indonesia dan Kumpulan Organisasi Masyarakat Peduli Anak.

\section{PENUTUP}

\section{Kesimpulan}

Sejak Pemerintah Daerah Kabupaten Sumbawa mulai mengimplementasikan kebijakan tentang Kabupaten Sumbawa Layak Anak pada tahun 2017, implementasi pemenuhan hak anak dan penguatan kelembagaan sepenuhnya belum tercapai secara maksimal. Adapun beberapa aspek penguatan kelembagaan yang sudah dicapai yaitu: (a) 
terbentuknya Gugus Tugas Kabupaten Sumbawa Layak Anak dan tim penyusun Rencana Aksi Daerah (b) terbentuknya Forum Anak; dan (c) tersusunnya Peraturan Daerah tentang Perlindungan Anak yang merupakan bagian dari KLA.

Kelembagaan KLA di level kabupaten belum sepenuhnya dapat berjalan karena banyak hal, seperti di dalam internal kelembagaan itu sendiri belum berjalan koordinasi yang baik antar OPD yang merupakan bagian dari Gugus Tugas KLA dan belum tersedianya Rencana Aksi Daerah (RAD). Kondisi ini turut diperburuk dengan tidak tersedinya profil anak di Kabupaten Sumbawa serta belum ada keikutsertaan masyarakat, Lembaga swadaya masyarakat, dunia usaha, dan jaringan media peduli anak.

Implementasi pemenuhan hak anak berdasarkan klaster di Kabupaten Sumbawa juga belum maksimal. Hal ini ditunjukkan pencapaian tiap-tiap klaster belum terpenuhi secara keseluruhan dan masih dibawah target rencana pencapaian yang telah ditetapkan oleh pemerintah daerah kabupaten Sumbawa pada tahun 2017 maupun tahun 2018. Hambatan dalam implementasi KLA terletak pada aspek kelembagaan dan penyedian Informasi Layak Anak. Kelembagaan KLA belum memadai dan belum tersedia informasi terpadu tentang hak anak yang mengakibatkan anak-anak tidak dapat mengakses segala informasi sesuai usia. Serta, orang tua tidak memperoleh pemahaman mengenai konten yang layak anak karena keterbatasan informasi.

\section{REFERENSI}

Affandi A, et all. 2014. Modul Participatory Action Research (PAR); Untuk Pengor-ganisasian Mayarakat (Community Organizing). Surabaya: LPPM UIN Sunan Ampel.

Kabupaten Sumbawa. 2016. Rencana Pembangunan Jangka Menengah (RPJM) 2016-2021. Sumbawa Besar: Kabupaten Sumbawa.

Kabupaten Sumbawa. 2017. Peraturan Daerah No. 7 Tahun 2017 tentang Penyelenggaraan Perlindungan Anak. Sumbawa Besar: Kabupaten Sumbawa.

Kabupaten Sumbawa. 2017. Laporan Kinerja Instansi Pemerintah (LKJIP) Dinas Pe- ngendalian Penduduk, Keluarga Berencana, Pemberdayaan Perempuan dan Perlindungan Anak. Sumbawa Besar: Kabupaten Sumbawa.

Kabupaten Sumbawa. 2017. Laporan Badan Pusat Statistik Kabupaten Sumbawa 2017. Sumbawa Besar: Kabupaten Sumbawa.

Persatuan Bangsa Bangsa. 1989. Konvensi Hak Anak melalui Resolusi No. 44/25. New York: PBB

Provinsi Nusa Tenggara Barat. 2018. Data BPS tentang Jumlah Penduduk Menurut Kabupaten/Kota. Mataram: Provinsi NTB

Republik Indonesia. 2011. Peraturan Menteri Pemberdayaan Perempuan dan Perlindungan Anak No. 11 Tahun 2011 tentang Kebijakan Pengembangan Kabupaten/Kota Layak Anak. Jakarta: Republik Indonesia.

Republik Indonesia. 2011. Peraturan Menteri Pemberdayaan Perempuan dan Perlindungan Anak No. 12 Tahun 2011 tentang Indikator Pengembangan Kabupaten/Kota Layak Anak. Jakarta: Republik Indonesia.

Republik Indonesia. 2014. Undang-undang No.35 Tahun 2014 tentang perubahan UU No. 23 Tahun 2002 tentang Perlindungan Anak. Jakarta: Republik Indonesia.

Samawa Center. 2018. Laporan hasil Focus Group Discussion bersama OPD Kabupaten Sumbawa di Kantor BAPPEDA. Sumbawa Besar: Samawa Center.

Samawa Center. 2018. Laporan pengisian indikator Pengembangan KLA beserta lampiran dokumen dari OPD Kabupaten Sumbawa. Sumbawa Besar: Sanmawa Center.

\section{Internet}

Jawapos.com. 2017. "126 daerah raih penghargaan kota layak anak." Retrieved (https://www.jawapos.com/read/2017/12/27/ 177652/126-daerah-raih-penghargaan-kotalayak-anak) 